\title{
FERTILIZER METERING MECHANISM WITH HELICAL CONIC CYLINDRICAL THREAD FOR FAMILY AGRICULTURE
}

\author{
Cezario B. Galvão ${ }^{*}$, Daniel Albiero ${ }^{2,3}$, Angel P. Garcia ${ }^{2}$, Leonardo de A. Monteiro ${ }^{3}$
}

${ }^{1 *}$ Corresponding author. Faculdade de Engenharia Agrícola da Universidade Estadual de Campinas (FEAGRI/UNICAMP)/
Campinas - SP, Brasil. E-mail: cezario.galvao@feagri.unicamp.br

\section{KEYWORDS \\ distribution of fertilizers, family agriculture, helical conic thread.}

\begin{abstract}
Small rural farms are important for Brazilian agribusiness, but equipment suitable for distributing fertilizers on these properties is scarce. We studied a new fertilizer metering mechanism for use on the family farm. It combines a helical conic thread with a conventional fertilizer meter in a cylindrical section. The experimental plan was created using a $2^{4}$ factorial design. An analysis of variance (ANOVA) was also conducted. The mechanism showed a positive result with respect to the uniformity of fertilizer flow (with a coefficient of variation of 3.1-5.8\%), longitudinal distribution (with a coefficient of variation of $4 \%$ ), and different types of fertilizers (in which variations between 2.7 and $3.5 \%$ were found).
\end{abstract}

\section{INTRODUCTION}

In Brazil, there are 4.4 million family farms, which are $84 \%$ of rural properties and produce $38 \%$ of the gross value of agricultural products and $50 \%$ of the food for the Brazilian food basket (MDA, 2018). There are few tools, implements, and machines meant for this sector of agriculture (Stefanello et al., 2014; Vianna et al., 2014). Through public policies, the Brazilian government has provided family farmers with subsidized credit programs, including the National Program of Sustainable Family Agriculture (PRONAF) of the More Food Program (Programa Mais Alimentos), for the acquisition of agricultural machinery (Reis et al., 2014). However, one problem with this machinery is the lack of a fertilizer metering mechanism designed to operate at speeds compatible with animal traction or small tractors and wheel horses.

Approximately $90 \%$ of the seeders and fertilizer spreaders on the farm machinery market in Brazil are equipped with helical thread fertilizer metering. In general, this mechanism provides a largely uneven flow during longitudinal distribution, with a coefficient of variation exceeding $30 \%$, according to studies by Bonotto et al. (2013) and Franck et al. (2015). The objective of the study by Weirich Neto et al. (2015) was to establish quality standards for maize sowing; they concluded that variations in fertilizer dosage between rows should be below $5 \%$.
Our innovation unites two concepts of fertilizer metering: the helical conic thread of Chang (1995) and the helical cylindrical thread normally used in fertilizer distribution machines. The aim of this study was to show that the combination of these two concepts improves the flow and homogeneity of longitudinal fertilizer distribution for applications at low speeds and low axis rotation of the mechanism.

\section{MATERIAL AND METHODS}

To achieve the goal of this study, the statistical methodology of a $2^{4}$ factorial scheme proposed by Daniel (1976) was used to study the rate of advancement of a continuous flow sower as a function of four factors: seed load, seed flow rate, rotational speed, and type of seeding mechanism. A normal probability plot of estimated effects was used to identify which factors and factor interactions are significant.

The new helical conic cylindrical thread-type solid fertilizer metering mechanism (Figure 1) consists of two sections: a conductive thread shaped like a propeller and a conic propeller [Figure 1(c)], both made of nylon. The base structure, made of steel, has a rectangular opening at the top to allow the entry of the fertilizer into only the helical cylindrical part. The base structure contains a sleeve of the same shape and material as the conic thread because both pieces are in contact during operation of the mechanism [Figure 1(b)].

${ }^{2}$ Faculdade de Engenharia Agrícola da Universidade Estadual de Campinas (FEAGRI/UNICAMP)/ Campinas - SP, Brasil.

${ }^{3}$ Universidade Federal do Ceará (DENA/UFC)/ Fortaleza - CE, Brasil.

Received in: 8-10-2017

Accepted in: 10-25-2018 
The advantage of this new type of fertilizer metering mechanism is that it provides a more uniform longitudinal distribution of fertilizer due to volume concentration of the fertilizer by the conventional section in the conic area. This section possesses a uniform initial section and the same helical pitch as that of the cylindrical area. However, the progressive reduction of fertilizer volume transported is due to the decrease in the crosssectional area of the thread because of the geometrical relationship with the cone body, which causes a decrease in the available volumetric space for the outflow of fertilizer. This increases the density of the mass of granules, which significantly reduces the pulsation of the fertilizer distribution and thus leads to a more uniform distribution.

The thread pitch was $40 \mathrm{~mm}$ and the thread-sleeve gap was $0.1 \mathrm{~mm}$. The distribution rate was adjusted by varying the transmission system between the motor wheel and the axis of the fertilizer spreader.

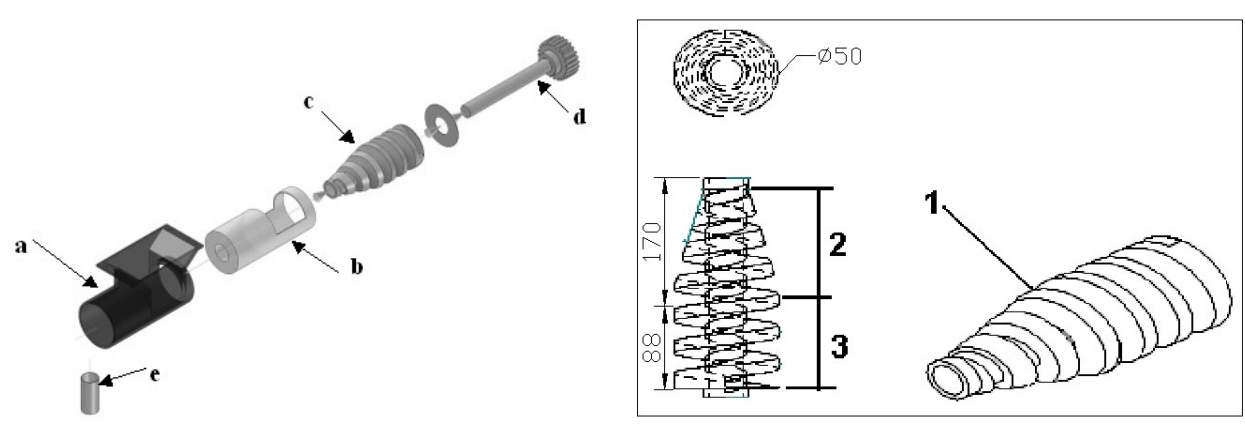

FIGURE 1. Fertilizer metering with helical conic thread: (a) base, (b) sleeve, (c) thread (1-helical conic thread, 2-conic part, 3-cylindrical part), (d) axis of the fertilizer spreader, (e) drain tube.

Evaluations were conducted using the methodology suggested by the Brazilian Association of Technical Standards (ABNT). Tests were carried out according to a factorial experimental plan for a full $2^{4}$ project, with the following factors: two reservoir levels, two movement speeds, two axis rotation speeds, and two mechanism positions, with 10 repetitions each.

The following variables were determined according to the recommendations of the standard "Line distribution of fertilizers or correctives-laboratory testing" (ABNT, 1996): flow of the mechanism, longitudinal distribution of the fertilizer, and application ratio (obtained as a function of longitudinal distribution). Each response variable must include the following factors: level of fertilizer in the reservoirs, movement speed and axis rotation of the mechanism, and position of the mechanism. The coding terminology of the trials as a function of these factors was Eabcd, where "a" is the variation of the reservoir load $[\mathrm{a}=$ 1 , full reservoir (1/1) with $40 \mathrm{~kg}$ of fertilizer; $\mathrm{a}=2,1 / 4$ reservoir (1/4) with $10 \mathrm{~kg}$ of fertilizer); "b" is the movement speed $\left(\mathrm{b}=1, v=0.69 \mathrm{~m} \mathrm{~s}^{-1} ; \mathrm{b}=2, v=1.11 \mathrm{~m}\right.$ $\left.\mathrm{s}^{-1}\right)$; " $\mathrm{c}$ " is the position of the reservoir $(\mathrm{c}=1$, reservoir is level cross-sectionally and longitudinally, $\mathrm{c}=2$, reservoir level longitudinally and inclined $11^{\circ}$ to the right); "d" is the axis rotation of the mechanism per linear meter $(d=1$, 2 rotations $\mathrm{m}^{-1}, \mathrm{~d}=2,3.18$ rotations $\left.\mathrm{m}^{-1}\right)$. The displacement speeds of $0.69 \mathrm{~m} \mathrm{~s}^{-1}\left(2.5 \mathrm{~km} \mathrm{~h}^{-1}\right)$ and $1.11 \mathrm{~m}$ $\mathrm{s}^{-1}\left(4.0 \mathrm{~km} \mathrm{~h}^{-1}\right)$ adopted in this study were those recommended by ABNT (1996) for a fertilizer metering mechanism moved by animal traction.

Bench tests were conducted whereby a soil box was moved over a system of rails powered by an electric motor with frequency inverter and current transmission. The axis feeder of the metering mechanism was coupled to the motor wheels. The transmission ratio was modified by changing the motor wheels, the diameters of which varied as follows: Wheel1, $100 \mathrm{~mm}$ diameter (equivalent to 3.18 axis rotations of the fertilizer spreader per covered meter) and Wheel2, $160 \mathrm{~mm}$ diameter (equivalent to 2.0 rotations of the fertilizer spreader per covered meter). The fertilization step was $10 \mathrm{~m}$. Only the samples at $6 \mathrm{~m}$ were collected, discarding the first and last $3 \mathrm{~m}$.

Longitudinal distribution was assessed using a 1-mlong half PVC pipe positioned along the deposition range. After the experiment, the six channels that covered the assessed $6 \mathrm{~m}$ were removed and the fertilizer was collected and weighted. Skidding was always $2 \%$.

Albiero et al. (2012) described a way of determining important factors in agricultural experiments, analyzing their effects on a normal probability plot. A significant effect is when a data point of a factor is far from the line by which the data are best adjusted. According to Barros Neto et al. (2003), an effect is significant only at $95 \%$ confidence if Effect $>t 4^{*}$, the standard deviation of the effect, which is the value of Student's $t$ distribution for a bilateral test for four degrees of freedom (2.776).

Experiments were performed using three different fertilizers: granulated fertilizer formula 5-20-20, granulated fertilizer formula 10-30-10, and granulated urea. These formulations were chosen because they are commonly used on crops such as sugarcane and beans. The analytical scale model A-1000 (No. 181460, Marte Balanças e Aparelhos de Precisão Ltda, São Paulo, Brazil), with a maximum load of $1000 \mathrm{~g}$ and an upper range limit of $0.005 \mathrm{~g}$, was used to verify the mass of fertilizer deposited on the ground.

According to ABNT (1996), the proper environmental conditions at which to perform the evaluations are wind speed $<2 \mathrm{~m} \mathrm{~s}^{-1}$ and relative humidity $<80 \%$. During our experiment, the following average values were recorded: $0 \mathrm{~mm}$ precipitation, $34 \%$ relative humidity, wind speed of $0.56 \mathrm{~m} \mathrm{~s}^{-1}$, and air temperature of $20{ }^{\circ} \mathrm{C}$.

To determine the physical characteristics of the fertilizers used, we followed the methodology described by Reynaldo \& Gamero (2015). The characteristics are presented in Table 1. 
TABLE 1. Physical properties of the fertilizers used.

$\left.\begin{array}{ccccc}\hline \text { Fertilizer } & \begin{array}{c}\text { Water content } \\ (\%)\end{array} & \begin{array}{c}\text { Density } \\ \left(\mathrm{kg} \mathrm{m}^{-3}\right)\end{array} & \text { Slope angle (degrees) } & \multicolumn{2}{c}{\text { Weighted mean diameter }} \\ (\mathrm{mm})\end{array}\right)$

In this study, the significance level considered was $5 \%$. The kurtosis and symmetry tests were used to evaluate the normality of the data distributions, with values for rejection of normality of $k>2$ or $k<-2$ (kurtosis test) and $g>2$ or $g<-2$ (symmetry test). The least significant difference test (LSD) was used to compare means. All statistical analyses were performed using the statistical software package Minitab 15.0 (Minitab Inc., State College, PA, USA).

\section{RESULTS AND DISCUSSION}

Figures 2(a) and (b) show the effects calculated for the longitudinal distribution and fertilizer flow as functions of factors A (fertilizer level in the reservoir), B (speed), C (position of the fertilizer spreader), and D (rotation of the fertilizer spreader axis). (a)

Normal Probability Plot

(Alpha $=, 05$ )

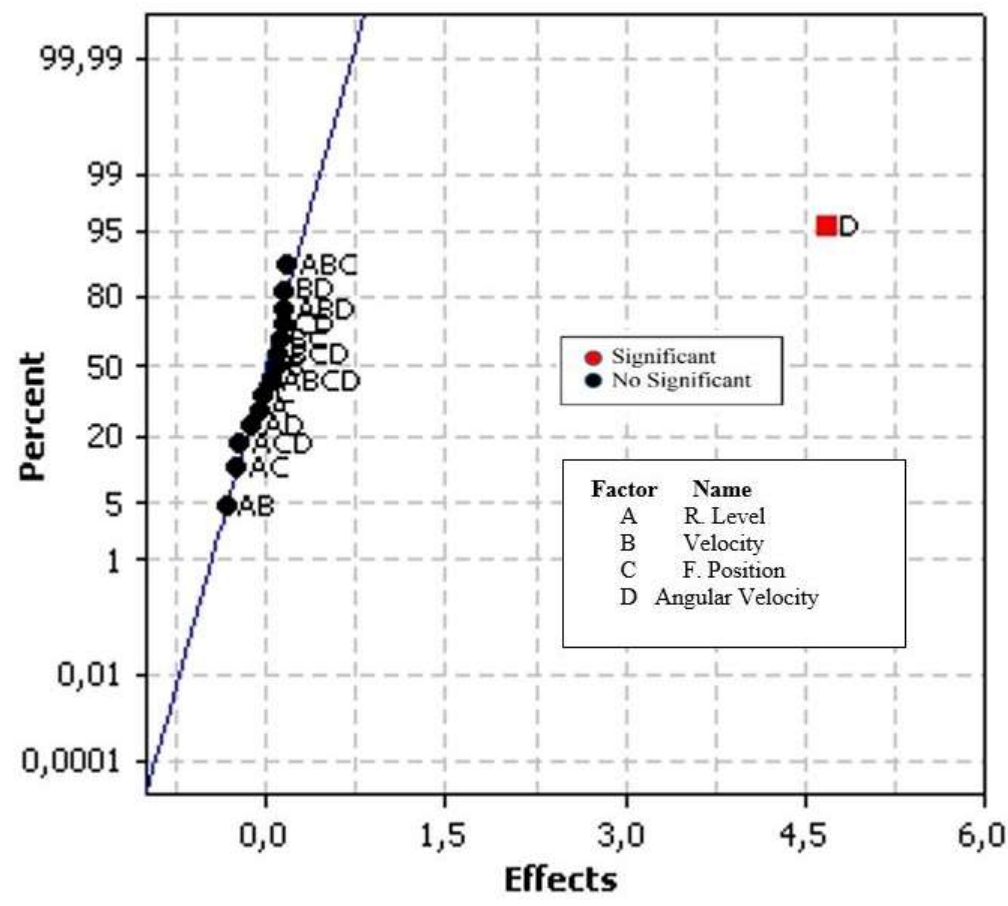




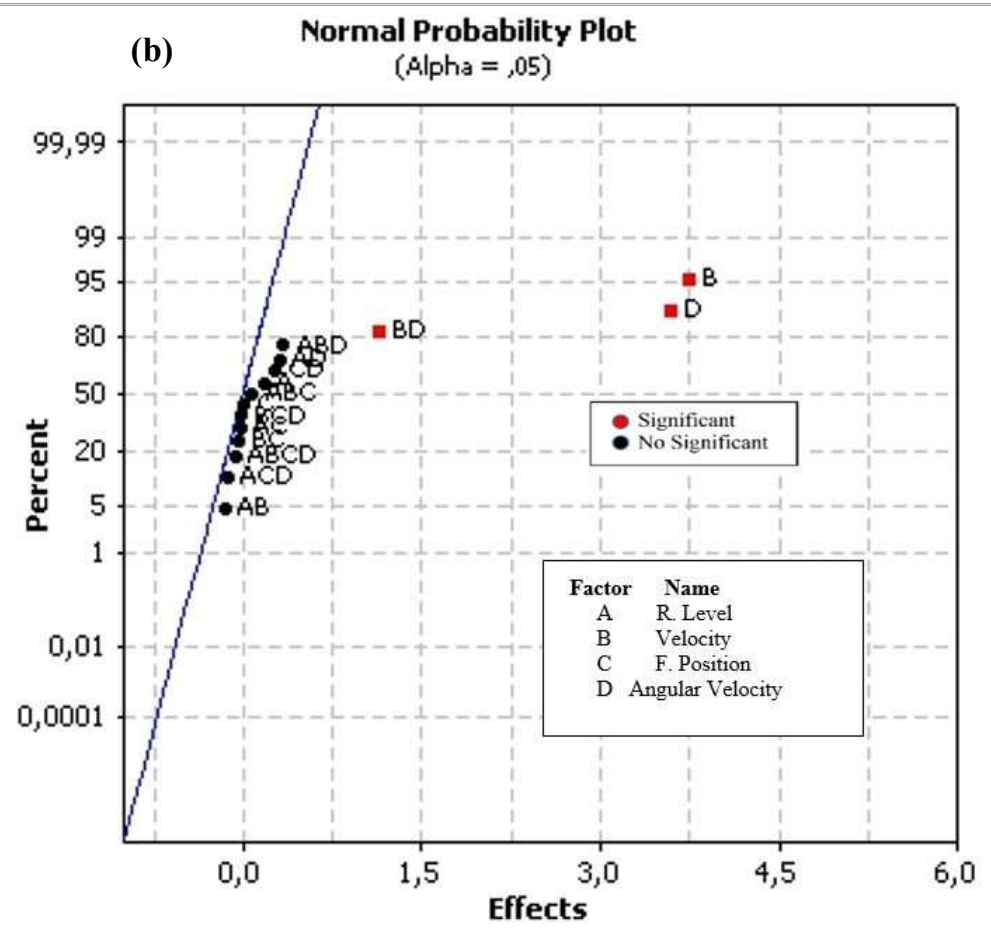

FIGURE 2. Normal probability plots of effects at 5\% significance: (a) longitudinal distribution response, (b) flow response.

For the longitudinal distribution variable [Figure 2(a)], one value of the effect of the axis rotation factor (D) (4.6858) was discrepant with respect to the effect values of the other factors (values $<1$ ). According to Albiero et al. (2012), analysis of the effects and of the normal probability plot reduces the amount of experimental work needed because it is possible to determine which factors are actually important to the phenomenon. Therefore, in our case, we prioritized the analysis of variance (ANOVA) of the two homogeneous groups: the longitudinal distribution as a function of D1 (two rotations per linear meter) and D2 (3.18 rotations per linear meter). Thus, it is possible to obtain only the data of the variable in question, with the focus on the variation of the axis rotation factor with all other factors fixed (Table 3).

Three distinct groups of factors affected fertilizer flow, indicated by the points outside the normal data distribution line in Figure 2(b), i.e., rotation of the fertilizer spreader axis (D), speed of the fertilizer spreader (B), and the interaction between these two factors (BD). This finding is significant because fertilizer flow is proportional to the mass as a function of time. Both the rotation of the fertilizer spreader axis and the speed of the fertilizer spreader influence the flow. Factors with nonsignificant effects were fixed and factors identified as important underwent ANOVA (Table 3).

The ANOVA was a simple classification type that uses the $\mathrm{F}$ ratio as the statistic, and the difference between the means was obtained via the LSD test. The normality of all treatment data underwent evaluation using the kurtosis $(k<2$ and $k>-2)$ and symmetry $(g<2$ and $g>-2)$ tests (Table 2). The data showed normality by being likely to undergo ANOVA via the F-test (Table 3). After assessing the significance of the treatments by ANOVA, we performed the LSD test for the means (Table 4).

TABLE 2. Evaluation of normality of data distributions, kurtosis, and symmetry .

\begin{tabular}{|c|c|c|c|c|c|c|}
\hline \multirow{2}{*}{ Treatment $^{\mathrm{b}}$} & \multicolumn{2}{|c|}{ Flow } & \multicolumn{2}{|c|}{ Distribution ratio } & \multicolumn{2}{|c|}{ Longitudinal distribution } \\
\hline & Symmetry & Kurtosis & Symmetry & Kurtosis & Symmetry & Kurtosis \\
\hline E1111 & -0.92 & -0.21 & -0.42 & -0.56 & -0.42 & -0.56 \\
\hline E1112 & 0.00 & -1.36 & -0.38 & -1.41 & -0.38 & -1.41 \\
\hline E1121 & -0.78 & -0.66 & -0.12 & -1.18 & -0.12 & -1.18 \\
\hline E1122 & -0.95 & -0.96 & -0.27 & -0.88 & -0.27 & -0.88 \\
\hline E1211 & -0.11 & -1.05 & 0.00 & -0.91 & 0.00 & -0.91 \\
\hline E1212 & -0.01 & -0.27 & -1.48 & -0.15 & -1.48 & -0.15 \\
\hline E1221 & -0.01 & -0.90 & -0.27 & -0.69 & -0.27 & -0.69 \\
\hline E1222 & 0.03 & -0.80 & -0.12 & -1.25 & -0.12 & -1.25 \\
\hline E2111 & -1.20 & -0.21 & -0.27 & -0.56 & -0.27 & -0.56 \\
\hline $\mathrm{E} 2112$ & 0.00 & -1.36 & 0.00 & -1.41 & 0.00 & -1.41 \\
\hline $\mathrm{E} 2121$ & -0.86 & -0.66 & -0.50 & -1.18 & -0.50 & -1.18 \\
\hline E2122 & 1.05 & 1.80 & -0.38 & -0.42 & -0.38 & -0.42 \\
\hline E2211 & -0.19 & -1.25 & -1.33 & -0.38 & -1.33 & -0.38 \\
\hline E2212 & 0.07 & -1.35 & -0.45 & -0.12 & -0.45 & -0.12 \\
\hline E2221 & -0.01 & -1.37 & 1.80 & -0.27 & 1.80 & -0.27 \\
\hline E2222 & 0.04 & -1.34 & -1.25 & 0.00 & -1.25 & 0.00 \\
\hline
\end{tabular}

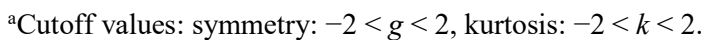

${ }^{b}$ Coding: Eabcd, where (a) is the reservoir level, (b) is the speed, (c) is the level of the fertilizer spreader, and (d) is the axis rotation per linear meter. 
TABLE 3. Descriptive statistics and ANOVA of the longitudinal distribution and fertilizer flow.

\begin{tabular}{|c|c|c|c|c|c|c|c|c|}
\hline \multicolumn{9}{|c|}{ Longitudinal distribution } \\
\hline Axis rotation $^{\mathrm{a}}$ & $\begin{array}{c}\text { Mean } \\
\left(\mathrm{g} \mathrm{m}^{-1}\right)\end{array}$ & $\begin{array}{c}\mathrm{DP}^{\mathrm{b}} \\
\left(\mathrm{g} \mathrm{m}^{-1}\right) \\
\end{array}$ & $\begin{array}{l}\mathrm{VC}^{\mathrm{b}} \\
(\%) \\
\end{array}$ & g rotation $^{-1}$ & $\begin{array}{c}\text { Maximum } \\
\left(\mathrm{g} \mathrm{m}^{-1}\right)\end{array}$ & $\begin{array}{c}\text { Minimum } \\
\left(\mathrm{g} \mathrm{m}^{-1}\right)\end{array}$ & $\mathrm{F}$ ratio (intergroup) & $p$-value \\
\hline Eabc1 (2.0) & 6.60 & 0.26 & 4.1 & 3.30 & 7.27 & 6.27 & 2.47 & 0.0636 \\
\hline Eabc2 (3.18) & 10.47 & 0.43 & 4.7 & 3.29 & 11.20 & 9.79 & 1.38 & 0.2788 \\
\hline $\begin{array}{c}\text { F ratio } \\
\text { intergroup }\end{array}$ & & & & & 222.33 & & & 0.000 \\
\hline \multicolumn{9}{|c|}{ Flow } \\
\hline Axis rotation/speed & $\begin{array}{l}\text { Mean } \\
\left(\mathrm{g} \mathrm{s}^{-1}\right)\end{array}$ & $\begin{array}{c}\text { DP } \\
\left(\mathrm{g} \mathrm{s}^{-1}\right)\end{array}$ & $\begin{array}{l}\mathrm{VC} \\
(\%)\end{array}$ & $\mathrm{g}$ rotation $^{-1}$ & $\begin{array}{c}\text { Maximum } \\
\left(\mathrm{g} \mathrm{s}^{-1}\right)\end{array}$ & $\begin{array}{c}\text { Minimum } \\
\left(\mathrm{g} \mathrm{s}^{-1}\right)\end{array}$ & $\begin{array}{c}\text { F ratio } \\
\text { (intergroup) }\end{array}$ & $p$-value \\
\hline Ea1c1 (2/0.69) & 4.34 & 0.23 & 5.3 & 3.14 & 4.63 & 4.08 & 22.89 & 0.32 \\
\hline $\mathrm{Ea} 1 \mathrm{c} 2 / \mathrm{Ea} 2 \mathrm{c} 1$ & 7.02 & 0.31 & 4.4 & 3.16 & 7.38 & 6.62 & 37.98 & 0.26 \\
\hline $\operatorname{Ea} 2 \mathrm{c} 2(3.18 / 1.11)$ & 11.92 & 0.54 & 4.5 & 3.37 & 12.43 & 11.28 & 90.4 & 0.1 \\
\hline $\begin{array}{l}\text { F ratio } \\
\text { intergroup }\end{array}$ & & & & & 324.93 & & & 0.000 \\
\hline
\end{tabular}

${ }^{a}$ Coding: Eabcd, where (a) is the reservoir level, (b) is the speed, (c) is the level of the fertilizer spreader, and (d) is the axis rotation per linear meter. ${ }^{\mathrm{b}} \mathrm{DP}=$ Product density and $\mathrm{VC}=$ Coefficient of variation .

The results presented in Table 3 for longitudinal distribution show that there was no statistically significant difference within the specific groups. However, there was a significant difference between groups when comparing the Eabc1 and Eabc2 treatments, which demonstrated that there was a statistically significant difference between the treatments.

The results presented in Table 3 also show that the same observations can be made with respect to flow, i.e., there was no statistically significant difference within the treatments Ea1c1, Ea1c2, and Ea2c2, but there was a statistically significant difference between the treatments.
Table 3 verifies that the longitudinal distribution had good regularity with respect to the rotation of the axis of the new fertilizer spreader. The coefficient of variation was low for both groups, and the mechanism kept the mean of the mass of fertilizer deposited for each rotation virtually unchanged. With respect to flow, there was a noticeable significant difference among the three homogeneous groups, as seen in Figure 2(b). The ratio of mass distributed to rotation speed remained practically unchanged apart from the flow presenting a low coefficient of variation.

TABLE 4. Mean values ( \pm standard deviation) and LSD test for different combinations of factors.

\begin{tabular}{|c|c|c|c|c|c|c|c|}
\hline $\begin{array}{c}\text { Treatment } \\
\text { Average of } \\
10 \\
\text { repetitions** }\end{array}$ & $\begin{array}{l}\text { Driving } \\
\text { wheel } \\
\text { skidding } \\
(\%) \\
\end{array}$ & $\begin{array}{l}\text { Flow } \\
\left(\mathrm{g} \mathrm{s}^{-1}\right)\end{array}$ & $\begin{array}{l}\text { CV of flow } \\
(\%)^{* * *}\end{array}$ & $\begin{array}{l}\text { Longitudinal } \\
\text { distribution } \\
\left(\mathrm{g} \mathrm{m}^{-1}\right)\end{array}$ & $\begin{array}{c}\mathrm{CV} \text { of } \\
\text { longitudinal } \\
\text { distribution } \\
(\%)^{* * *}\end{array}$ & $\begin{array}{l}\text { Distribution ratio } \\
\qquad\left(\mathrm{kg} \mathrm{ha}^{-1}\right)^{*}\end{array}$ & $\begin{array}{c}\mathrm{CV} \text { of } \\
\text { distribution } \\
\text { ratio } \\
\left(\mathrm{kg} \mathrm{ha}^{-1}\right)^{* * *} \\
\end{array}$ \\
\hline E1111 & 2 & $4.27 \pm 0.13^{\mathrm{e}}$ & 3.1 & $6.19 \pm 0.26^{\mathrm{a}}$ & 4.2 & $133.98 \pm 4.15^{\mathrm{c}}$ & 3.1 \\
\hline E1112 & 2 & $6.62 \pm 0.26^{\mathrm{g}}$ & 3.9 & $9.60 \pm 0.40^{b}$ & 4.1 & $195.89 \pm 7.64^{d}$ & 3.9 \\
\hline E1121 & 2 & $4.08 \pm 0.18^{\mathrm{e}}$ & 4.3 & $5.92 \pm 0.25^{\mathrm{a}}$ & 4.2 & $128.05 \pm 5.51^{\mathrm{c}}$ & 4.3 \\
\hline E1122 & 2 & $7.10 \pm 0.36^{\mathrm{g}}$ & 5.1 & $10.28 \pm 0.43^{b}$ & 4.1 & $209.88 \pm 10.70^{d}$ & 5.1 \\
\hline E1211 & 2 & $7.29 \pm 0.35^{\mathrm{g}}$ & 4.8 & $6.57 \pm 0.27^{\mathrm{a}}$ & 4.1 & $142.04 \pm 6.82^{\mathrm{c}}$ & 4.8 \\
\hline E1212 & 2 & $11.28 \pm 0.52^{\mathrm{f}}$ & 4.6 & $10.16 \pm 0.42^{b}$ & 4.1 & $207.34 \pm 9.54^{d}$ & 4.6 \\
\hline E1221 & 2 & $6.79 \pm 0.30^{\mathrm{g}}$ & 4.4 & $6.12 \pm 0.25^{\mathrm{a}}$ & 4.0 & $132.29 \pm 5.82^{c}$ & 4.4 \\
\hline E1222 & 2 & $11.66 \pm 0.55^{\mathrm{f}}$ & 4.7 & $10.50 \pm 0.44^{b}$ & 4.2 & $214.33 \pm 10.07^{\mathrm{d}}$ & 4.7 \\
\hline E2111 & 2 & $4.64 \pm 0.24^{\mathrm{e}}$ & 5.1 & $6.72 \pm 0.28^{a}$ & 4.1 & $145.43 \pm 7.42^{\mathrm{c}}$ & 5.1 \\
\hline E2112 & 2 & $7.05 \pm 0.39^{g}$ & 5.5 & $10.22 \pm 0.42^{b}$ & 4.0 & $208.61 \pm 11.47^{\mathrm{d}}$ & 5.5 \\
\hline E2121 & 2 & $4.38 \pm 0.25^{\mathrm{e}}$ & 5.8 & $6.35 \pm 0.26^{\mathrm{a}}$ & 4.1 & $137.38 \pm 7.97^{\mathrm{c}}$ & 5.8 \\
\hline E2122 & 2 & $7.38 \pm 0.40^{\mathrm{g}}$ & 5.4 & $10.70 \pm 0.44^{b}$ & 4.1 & $214.00 \pm 11.56^{\mathrm{d}}$ & 5.4 \\
\hline E2211 & 2 & $6.99 \pm 0.31^{\mathrm{g}}$ & 4.5 & $6.30 \pm 0.26^{\mathrm{a}}$ & 4.1 & $126.00 \pm 5.67^{\mathrm{c}}$ & 4.5 \\
\hline E2212 & 2 & $12.32 \pm 0.69^{\mathrm{f}}$ & 5.6 & $11.1 \pm 0.46^{\mathrm{b}}$ & 4.1 & $222.00 \pm 12.43^{\mathrm{d}}$ & 5.6 \\
\hline E2221 & 2 & $6.96 \pm 0.30^{\mathrm{g}}$ & 4.3 & $6.27 \pm 0.26^{\mathrm{a}}$ & 4.1 & $125.40 \pm 5.39^{c}$ & 4.3 \\
\hline E2222 & 2 & $12.43 \pm 0.53^{\mathrm{f}}$ & 4.3 & $11.20 \pm 0.46^{\mathrm{b}}$ & 4.1 & $224.00 \pm 9.63^{\mathrm{d}}$ & 4.3 \\
\hline
\end{tabular}

$\mathrm{CV}=$ coefficient of variation.

*For a longitudinal distribution at a spacing of $0.5 \mathrm{~m} \mathrm{ha}^{-1}$.

**Coding: Eabcd, where (a) is the reservoir level, (b) is the speed, (c) is the level of the fertilizer spreader, and (d) is the axis rotation per linear meter.

***The coefficients of variation for flow and distribution ratio are equal because both flow and distribution ratio are dependent variables and the factors speed and spacing are constant.

${ }^{\mathrm{a}-\mathrm{g}}$ The presence of the same letters indicates the absence of a statistically significant difference at the $95 \%$ level among the means according to the LSD test. 
The results for the longitudinal distribution presented in Table 4 confirm the statistical behavior found by performing the analysis of effects on a normal probability plot [Figure 2(a)], because before the treatments listed in Table 4, the only factor that affected the longitudinal distribution variable was the axis rotation per linear meter (d). The other factors in their various combinations did not affect the longitudinal distribution of the fertilizer.

Table 4 also confirms the analysis presented in Figure 2(b) with respect to flow. There was no statistically significant difference between the treatments with variations between the speed (b) and the axis rotation (d) of the spreader. This is verified by comparing treatments E1111 and E1212. In this comparison, there is differentiation in terms of speed and axis rotation, which comprise an effect of interaction between these factors. Table 4 shows that there is a large difference between the values for the variable flow for these two treatments.

Reynaldo \& Gamero (2015) evaluated the performance of a "worm"-type solid-fertilizer spiral metering system available on the market by subjecting it to simulations at different longitudinal and transverse inclinations $\left(-15^{\circ},-5^{\circ}, 0^{\circ},+5^{\circ}\right.$, and $\left.+15^{\circ}\right)$. They identified the models with the best dosage performance and the effects of dosage rates on the transverse and longitudinal gradients and found that the best coefficient of variation observed was $5.1 \%$. This value shows the good performance of the new helical conic cylindrical fertilizer thread metering mechanism. Garcia et al. (2012) obtained a coefficient of variation for flow of $11.4 \%$ for helical thread dosers by proposing an angular speed controller for the motor drive shaft. Garcia et al. (2017) analyzed the performance of different fertilizer metering mechanisms for planters as a function of longitudinal inclination. The mechanism with the lowest percentage variation in the average dosage of granule mixtures had a coefficient of variation of $6.5 \%$. In tests with no-till maize, $\mathrm{Fu}$ et al. (2018) used an electronic control system and 45-mm-long collectors to reduce the relative error of the fertilizer application rate to $3.8-4.9 \%$.

These coefficient of variation values show that the new helical conic cylindrical metering mechanism rivals much more accurate and advanced systems, such as the one studied by Yuan et al. (2010). They evaluated a fertilizer application system with a variable rate controlled by a grooved roller with high-precision Gaussian nonlinear control. The roller axis of this system was configured with an angular velocity of 0.5 rotation $\mathrm{s}^{-1}$. The authors concluded that in small application ratios $\left(<150 \mathrm{~kg} \mathrm{ha}^{-1}\right)$, the difference between the value that is regulated and the effectively applied value reached $10 \%$.

The helical conic cylindrical thread fertilizer metering mechanism has superior performance, because it reaches an angular velocity of 2 rotations s ${ }^{-1}$ with an Ea2c1 treatment, i.e., speed of $1.1 \mathrm{~m} \mathrm{~s}^{-1}$ and axis rotation of 2 rotations per linear meter. With this configuration, the difference between the applied and the regulated value reaches at most $4.8 \%$ for application ratios around $130 \mathrm{~kg}$ $\mathrm{ha}^{-1}$.

Baio et al. (2012) stated that to achieve good agricultural productivity, it is essential to use the prescribed fertilizer dosage. In this context, our mechanism has obtained good results because the coefficients of variation of the application ratio were small in comparison to the results of Molin et al. (2010), who obtained a coefficient of variation of $18 \%$ for potassium distribution in an application of $170 \mathrm{~kg} \mathrm{ha}^{-1}$ using a fertilizer spreader with variable rates produced by independent mills.

To see if the type of fertilizer used affects the longitudinal distribution and the fertilizer flow, the metering mechanism was tested using three different fertilizers. The data are presented in Table 5.

TABLE 5. Descriptive statistics and ANOVA of the longitudinal distribution and fertilizer flow for several fertilizers using the E1111 combination of factors ${ }^{\mathrm{a}}$.

\begin{tabular}{cccccccc}
\hline Fertilizers & $\begin{array}{c}\text { Mean } \\
\left(\mathrm{g} \mathrm{m}^{-1}\right)\end{array}$ & $\begin{array}{c}\mathrm{DP} \\
\left(\mathrm{g} \mathrm{m}^{-1}\right)\end{array}$ & $\begin{array}{c}\mathrm{VC} \\
(\%)\end{array}$ & g rotation $^{-1}$ & $\begin{array}{c}\text { Maximum } \\
\left(\mathrm{g} \mathrm{m}^{-1}\right)\end{array}$ & $\begin{array}{c}\text { Minimum } \\
\left(\mathrm{g} \mathrm{m}^{-1}\right)\end{array}$ & $\begin{array}{c}\text { F ratio } \\
\text { Longitudinal distribution }\end{array}$ \\
\hline $05-20-20$ & 6.19 & 0.26 & 4.2 & 3.09 & 6.57 & 5.99 & 2.48 \\
Urea & 6.21 & 0.27 & 4.3 & 3.10 & 6.54 & 6.00 & 0.52 \\
$10-30-10$ & 6.20 & 0.25 & 4.0 & 3.10 & 6.49 & 6.11 & \\
\hline $05-20-20$ & 4.30 & 0.12 & 2.7 & 3.11 & 4.41 & 4.21 & 2.76 \\
Urea & 4.26 & 0.13 & 3.0 & 3.08 & 4.30 & 4.25 & 0.46 \\
$10-30-10$ & 4.29 & 0.15 & 3.5 & 3.10 & 4.31 & 4.24 & \\
\hline
\end{tabular}

aFull reservoir, movement speed of $0.69 \mathrm{~m} \mathrm{~s}^{-1}$, the fertilizer spreader level cross-sectionally and longitudinally, and 2 rotations of the fertilizer spreader axis for every covered meter.

By ANOVA, the data in Table 5 shows that there is no significant difference at $95 \%$ with respect to the type of fertilizer used, provided it is granulated.

Kim et al. (2008) evaluated the fertilizer flow of a granulated fertilizer pneumatic applicator and showed that for the granulated fertilizer formula 22-12-12, the coefficients of variation ranged from $6 \%$ to $11 \%$. Barros et al. (2016) evaluated the performance of a variable-rate fertilizer distribution system for coffee crops. Two types of tests were performed: transverse deposition and longitudinal deposition. The distribution system remained stable during longitudinal deposition, with a maximum mean error of $-7.99 \%$ and a minimum of $-3.76 \%$. Because the helical conic cylindrical metering mechanism is not affected by the type of granulated fertilizer used or by its formulation, the new mechanism provides satisfactory results in terms of flow when its coefficient of variation of $\sim 3 \%$ is compared to other systems. Its results are also satisfactory with respect to longitudinal distribution of different fertilizers, as well as with other treatments, with a coefficient of variation of $\sim 4 \%$. 


\section{CONCLUSIONS}

The new helical conic thread distribution mechanism obtained good performance in terms of homogeneity and uniformity of the longitudinal distribution of fertilizers, with a coefficient of variation of around $4 \%$ for various treatments and different fertilizers. The new mechanism proved to be efficient with respect to flow, with a coefficient of variation ranging from $3.1 \%$ to $5.8 \%$ with various treatments. With different fertilizers, the coefficient of variation varied from $2.7 \%$ to $3.5 \%$.

The helical conic cylindrical thread fertilizer metering mechanism was not susceptible to the factor fertilizer level in the reservoir and the position of the fertilizer spreader. With respect to the axis rotation of the fertilizer spreader, the longitudinal distribution varied in proportion to the rotation of the motor wheel. Both axis rotation and speed caused variations in the flow.

\section{REFERENCES}

ABNT (1996) Projeto de norma 04:015.06.005/1996Distribuição em linha de fertilizantes ou corretivos: Ensaios de laboratório. Rio de Janeiro, ABNT-CB-04. 22p.

Albiero D, Maciel AJS, Lanças KP, Monteiro LA, Viliotti CA, Mion RL (2012) Gráficos de probabilidade normal para avaliação de mecanismos de distribuição de sementes em semeadoras. Semina: Ciências Agrárias 33(2):507-518.

Baio FHR, Molin JP, Leal AJF (2012) Avaliação comparativa da distribuição transversal de adubos sólidos aplicados em culturas anuais. Bioscience Journal 28(4):527-536.

Barros MM, Volpato CES, Silva FM, Conceição FG, Corrêa Júnior D, Ribeiro LF (2016) Performance of a variable-rate distribution system for simultaneous fertilizer application. Revista Brasileira de Engenharia Agrícola e Ambiental 20(2):188-192.

Barros Neto B, Scarminio IS, Bruns RE (2003) Como fazer experimentos. Campinas, Editora da UNICAMP, $430 \mathrm{p}$.

Bonotto GJ, Alonço AS, Bedin PR, Altmann AS, Moreira LJ (2013) Distribuição longitudinal de fertilizantes por dosadores de semeadoras-adubadoras em linha.

Engenharia na Agricultura 21(4):368-378.

Chang CS (1995) Desenvolvimento de novo conceito de rosca conico-helicoidal para possível aplicação em distribuidor de fertilizante para mecanização em Pequenas propriedades. Universidade de Campinas, Faculdade de Engenharia Agrícola, $10 \mathrm{p}$.

Daniel C (1976) Applications of statistics to industrial experimentation. New York, John Wiley and Sons, $480 \mathrm{p}$.
Franck CJ, Alonço AS, Machado ODC, Francetto TR, Carpes DP, Bellé MP (2015) Modelos estatísticos para seleção de dosadores helicoidais com diferentes dispositivos de descarga de fertilizante. Revista Brasileira de Engenharia Agrícola e Ambiental 19(5):512-518.

Fu W, Gao N, An X, Zhang J (2018) Study on precision application rate technology for maize no-tillage planter in North China Plain. IFAC Papers On Line 51(17):412-417.

Garcia AP, Cappelli NL, Umezu CK (2012) Auger-type granular fertylizer distributor: matemathical model and dynamic simulation. Engenharia Agrícola 32(1):151-163.

Garcia LC, Diniz RN, Rocha CH, Souza NM, Weirich Neto PH (2017) Performance of fertilizer metering mechanisms of planters as a function of longitudinal inclination. Engenharia Agrícola 37(6):1155-1162.

Kim YJ, Kim HJ, Ryu KH, Rhee JY (2008) Fertilizer application performance of a variable-rate pneumatic granular applicator for rice production. Biosystems Engineering 100(1):498-510.

Molin JP, Motormiya AVA, Frasson FR, Faulin GC, Tosta $\mathrm{W}$ (2010) Test procedure for variable rate fertilizer on coffe. Acta Scientiarum. Agronomy 32(4):569-575.

MDA - Ministério de Desenvolvimento Agrário. Plano Safra da Agricultura Familiar-2017/2020. Available in: http://www.mda.gov.br/sitemda/plano-safra-daagricultura-familiar-20172020. Accessed: Sep, 2018.

Reis AV, Machado ALT, Gomes MC, Anderson NLM, Machado RLT (2014) A multicriteria model to assess tractors used in family agriculture. Engenharia Agrícola 34(4):727-737.

Reynaldo EF, Gamero CA (2015) Avaliação de mecanismos dosadores de fertilizantes helicoidais em ângulos de nivelamento longitudinal e transversal. Energia na Agricultura 30(2):125-136.

Stefanello G, Machado ALT, Reis AV, Machado RLT, Morais CS (2014) Estrutura funcional de uma semeadora de tração humana. Ciência Rural 44(9):1583-1588.

Vianna LR, Reis AV, Machado ALT (2014) Development of a horizontal plate meter with double seed outlets. Revista Brasileira de Engenharia Agrícola e Ambiental 18(10):1086-1091.

Weirich Neto PH, Fornari AJ, Justino A, Garcia LC (2015) Quality in corn sowing. Engenharia Agrícola 35(1):171-179.

Yuan J, Liu CL, Zeng Q, Zha XF (2010) Gaussian process based bivariate control parameters optimization of variable-rate granular fertilizer applicator. Computer and Eletronics in Agriculture 70:33-41. 